\title{
AMERICAN
}

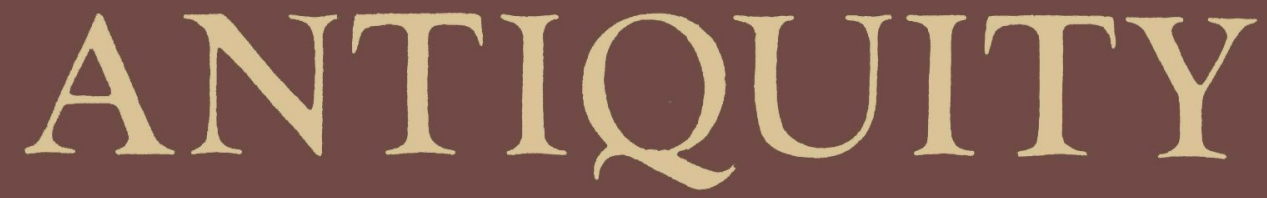

VOLUME XXIII

NUMBER 3

JANUARY, 1958

PUBLISHED BY THE SOCIETY FOR AMERICAN ARCHAEOLOGY 


\section{THE SOCIETY FOR AMERICAN ARCHAEOLOGY}

President: George I. Quimby, Chicago Natural History Museum, Chicago 5, Ill.

First Vice-President: Alex D. Krieger, Municipal Museum, Riverside, Calif.

Second Vice-President: Kenneth E. Kidd, Royal Ontario Museum of Archaeology, Toronto 5, Canada.

Secretary: David A. Baerreis, Sterling Hall, Univ. of Wisconsin, Madison 6.

Treasurer: James L. Swauger, Carnegie Museum, Pittsburgh 13, Pa.

Editor: Richard B. Woodbury, Dept. of Anthro., Columbia Univ., New York 27.

Associate Editor for Notes and News: Clement W. Meighan, Dept. of Anthro. and Soc., Univ. of Calif., Los Angeles 24.

Associate Editor for Reviews: Raymond H. Thompson, Dept. of Anthro., Univ. of Arizona, Tucson.

Assistant Editors: Early Man, Alex D. Krieger, Municipal Museum, Riverside, Calif.; Arctic, Elmer Harp, Jr., Dept. of Soc. and Anthro., Dartmouth College, Hanover, N.H.; Pacific Coast, Richard D. Daugherty, Dept. of Anthro., State College of Washington, Pullman; Southwest, Robert H. Lister, Dept. of Anthro., Univ. of Colorado, Boulder; Plains, E. Mott Davis, Dept. of Anthro., Univ. of Texas, Austin 12; Northern Mississippi Valley, Melvin L. Fowler, Illinois State Museum, Springfield; Northeast, Alfred K. Guthe, Rochester Museum of Arts and Sciences, Rochester, N.Y.; Southeast, William H. Sears, Florida State Museum, Gainesville; Middle America, Tatiana Proskouriakoff, Carnegie Institution of Washington, 10 Frisbie Place, Cambridge 38, Mass.; Highland South America, Gerardo Reichel-Dolmatoff, Apartado aéreo 146, Cartagena, Colombia; Lowland South America, Betty J. Meggers, U.S. National Museum, Washington 25, D.C.

Editorial Assistant: Nathalie F. S. Woodbury, Dept. of Anthro., Barnard Cullege, New York 27.

Members of the Executive Committee in addition to elected officers: Robert E. Bell (to 1959), Dept. of Anthro., University of Oklahoma, Norman; Clarence H. Webb (to 1959), 1560 Line Ave., Shreveport, La.; Frederick Johnson (to 1958), R. S. Peabody Foundation, Andover, Mass.; J. Alden Mason (to 1958), University Museum, Univ. of Pennsylvania, Philadelphia 4.

American Antiquity is published by the SocietY FOR AMERICAN ARCHakology during the months of January, April, July, and October. Subscription is by membership; annual dues are $\$ 8.0_{0}$, of which $\$ 7.00$ is for a subscription to American Antiquity and other publications as issued.

American Antiquity is printed by the University of Utah Press, Salt Lake City 12, Itah.

Entered as second-class matter June 1, 1951, at the post office at Salt Lake City, Utah, under the Act of March 3, 1879.

Articles and "Facts and Comments" should be submitted to the Editor, publications for review to the Review Editor, and information for "Notes and News" to the appropriate Assistant Editor.

Orders for back issues and memoirs should be sent to the Society for American Archaeology, Logan Museum, Beloit College, Beloit, Wisconsin. Payment should accompany order. See inside back cover for prices.

Please address requests for membership or other information to the Secretary. 